\title{
PENERAPAN METODE INQUIRY UNTUK MENINGKATKAN HASIL BELAJAR SISWA PADA MATA PELAJARAN IPA KELAS V SDN 4 KALIMAS KECAMATAN TELUK BATANG
}

\author{
Nurilla \\ SDN 4 Kalimas \\ Email: nurillasdn4kalimas@gmail.com
}

\begin{abstract}
Abstrak
Science subject is one of the curricular fields of study at the Elementary School (SD) level. Due to the low understanding of students towards this subject, especially the application of the inquiry method to improve student learning outcomes in class V SD Negeri 4 Kalimas, the writer makes improvements to learning. This study aims to improve students' learning outcomes and activities in science subjects using the inquiry method application material. After carrying out the teaching and learning activities using the inquiry method, student learning outcomes and activities have increased. This was shown from the data collected, that in the pre-cycle learning activities there are only 7 students who got a score $\geq$ minimun standard achievement with a class average score of 41.5. So the description of the data collected can be concluded that the use of the inquiry method can improve students' learning outcomes and activities in science subjects of class V SD Negeri 4 Kalimas. Thus, the inquiry method is one of the effective learning methods in improving students' learning outcomes and activities in science subjects.
\end{abstract}

\section{Keywords: Method, Inquiry, Learning Outcomes}

\section{PENDAHULUAN}

Peningkatan mutu pendidikan dewasa ini merupakan kebutuhan yang sangat mendesak dan harus dicari jalan keluarnya. Karena pendidikan merupan sarana yang sangat penting bagi setiap kehidupan manusia untuk meningkatkan daya saing dalam percaturan politik, ekonomi, hokum, budaya dan pertahanan pada tatanan kehidupan masyarakat dunia global.

Sadar akan hal itu, negara maju sekalipun selalu membangun dunia pendidikannya tanpa henti. Bahkan ada kecenderungan yang amat jelas bahwa, Negara maju semakin meningkat investasinya dalam dunia pendidikan. Semakin intensif maelakukan investasi dalam dunia pendidikan semungkin meningkatkan daya saing memerlukan kualitas sumber daya manusia yang berkualitas dan berdaya guna.

Sumber daya manusia yang berkualitas harus tercapai melalui pendidikan seperti tertuang dalam tujuan Pendidikan Nasional yaitu mencerdaskan kehidupan bangsa dan mengembangkan manusia Indonesia seutuhnya yaitu manusia yang beriman dan bertaqwa terhadap Tuhan Yang Maha Esa dan berbudi luhur memiliki pengetahuan dan keterampilan sehat jasmani dan rohani berkepribadian yang mantap dan mandiri serta memiliki rasa tanggung jawab kemasyrakatan dan kebangsaan.

Khusus pada proses belajar mengajar, peran serta guru sangat besar dalam pengelolan kelas, karena guru sebagai penanggung jawab kegiatan belajar mengajar sehingga guru dituntutpenuh kreatifitas dalam mengelola kelas. Dalam menjalankan tugasnya seorang guru setidaknya harus mempunyai kemampuan menguasai berbagai metode mengajar, serta mampu memilih metode yang tepat sesuai materi pelajaran, tingkat kecerdasan murid dan lingkungan serta kondisi setempat.

Menurut penulis pada pelajaran IPA aktifitas kelas sangat didominasi guru dengan metode yang monoton yang aktif variatif sehingga kurang menarik minat murid dan menyebabkan rendahnya pencapaian hasil belajar. Pelajaran IPA menjadi kumpulan data dan fakta yang harus dihafal, pelajaran yang tidak melibatkan emosi murid, padahal pelajaran IPA adalah pelajaran tentang manusia dan peristiwa. Untuk mengatasi kendala tersebut hendaknya murid diaktifkan dengan mendorong murid untuk mencari dan menemukan sendiri jawaban atas masalah-masalah yang dihadapi. Serta dapat mengumpulkan sendiri masalah tersebut melalui proses berfikir, logis dan sistematis. 
Berdasarkan hasil temuan penulis dapat diketahui kurangnya perhatian murid pada pelajaran IPA adalah karena sebagian siswa ada yang bermain, melamun, ngobrol, sehingga kelas tidak antusias menjawab dengan pasti tetapi mengambang bahkan menjawab tetapi menyimpang, dapat dikatakan pelajaran IPA tidak menarik karena menonton guru tidak memvariasikan metode. Hal tersebut akan berakibat pada rendahnya perolehan murid pada sebelum menggunakan metode inquiry.

Agar penerapan metode inquiry berfungsi efektif, guru hendaknya memberikan pujian kepada siswa seperti keantusiasan, keaktifan, kebermaknaan, menghindari respon yang negatif, juga harus diingat dalam pemberian pujian dan perhatian guru hendaknya memperhatikan hal-hal sasaran pujian, waktu pujian dan variasi penggunaannya.

Dalam melaksanakan perbaikan, penulis dibantu Supervisor untuk pelaksanaanya. Penulis merasakan dalam proses pembelajaran dengan mencoba beberapa metode yang ada. Pembelajaran kurang antusias dalam pembelajaran, ada yang ngobrol, melamun dan diam saja. Dari tes formatif yang dilakukan penulis pada akhir pembelajaran terlihat perolehan hasilnya.

Dalam melaksanakan perbaikan, penulis diantu teman sejawat untuk pelaksanaanya. Penulis merasakan dalam proses pembelajaran dengan mencoba beberapa metode yang ada. Pelajaran kurang efektif. Hal ini terkait adanya beberapa siswa yang kurang antusias dalam pembelajaran, ada yang ngobrol, melamun dan diam saja. Dari tes formatif yang dilakukan penulis pada akhir pembelajaran terlihat perolehan hasilnya sangat rendah ini dibuktikan dari 20 siswa ternyata yang dapat mengerjakan atau menjawab dengan benar hanya 10 atau $50 \%$.

Berdasarkan hal tersebut, atas bantuan teman sejawat dan kepala sekolah dalam hasil diskusi teridentifikasi masalah yang antara lain : (1) Kurangnya media dan alat peraga yang relevan dengan materi pembelajaran. (2) Kurangnya guru dalam menerapkan metode inquiry. (3) Kurangnya guru dalam menggunakan metode alternatif. Berdasarkan identifikasi masalah tersebut di atas, agar penulis tidak terlalu luas dalam merumuskan masalah diperlukan adanya pembatasan masalah.

Melalui diskusi dengan pembimbing dan supervisor maka dapat diketahui penyebab rendahnya hasil belajar siswa pada setiap pembelajaran adalah sebagai berikut : (1) Rendahnya kreatifitas dan minat belajar kurang. (2) Tingkat penguasaan siswa terhadap materi pembelajaran kurang. (3) Siswa kurang tertarik terhadap materi yang berbelit-belit. (4) Guru berpenampilan kaku. (5) Metode pembelajaran yang monoton. (6) Orang tua kurang memotivasi belajar anaknya. (7) Kurangnya motivasi dan pemberian pujian kepada siswa. Dari beberapa motivasi dan analisa malasah di atas, masalah akan difokuskan pada penerapan metode inquiry dalam meningkatkan perhatian siswa terhadap mata pelajaran IPA Kelas V SDN 4 Kalimas Kecamatan Teluk Batang Kabupaten Kayong Utara Tahun Pelajaran 2018/2019.

Berdasarkan identifikasi masalah dan analisis masalah, penulis tertarik untuk mengangkat sebuah metode pembelajaran yang dikenal dengan metode inquiry, sebagai objek peneliti pada penulisan ini. Permasalahan yang timbul dapat dirumuskan sebagai berikut : Apakah penggunan metode inquiry mampu meningkatkan perhatian siswa terhadap mata pelajaran IPA Kelas V SDN 4 Kalimas Kecamatan Teluk Batang Kabupaten Kayong Utara Tahun Pelajaran 2018/2019.

Tujuan yang hendak dicapai dan diharapkan dalam penulisan laporan pemantapan kemapuan profesional melalui perbaikan pembelajaran ini adalah : (1) Meningkatkan kreatifitas dan minat belajar dalam mengikuti pembelajaran. (2) Meningkatkan perhatian siswa dalam pembelajaran. (3) Guru sedikit demi sedikit mengetahui strategi pembelajaran yang bervariasi, sehingga permasalahan-permasalahan yang dihadapidapat diminimalkan. (4) Meningkatkan prestasi belajar. (5) Meningkatkan kualitas pembelajaran dan membantu mewujudkan visi dan misi dari SDN 4 Kalimas Kecamatan Teluk Batang Kabupaten Kayong Utara Tahun Pelajaran 2018/2019. (6) Menumbuhkan rasa percaya diri pada siswa (7) Mengontrol tingkah laku siswa serta mendorong perilaku yang positif.

Dari hasil pelaksanaan pemantapan kemampuan professional melalui perbaikan pembelajaran ini akan bermanfaat : (1) Dapat memperluas wawasan guru. (2) Dapat meningkatkan keprofesionalan guru. (3) Siswa dapat tertarik dan bergairah dan kreatif dalam mengikuti pembelajaran. (4) Siswa akan lebih mudah mengikuti pembelajaran. (5) Penggunaan metode ini dapat meningkatkan kualitas pembelajaran dan membantu mewujudkan visi dan misi dari SDN 4 Kalimas Kecamatan Teluk Batang Kabupaten Kayong Utara.

Inquiry berasal dari Bahasa Inggris, inquiry sebuah kata kerja yang berarti menanyakan, menyelidiki dan memeriksa (Wojo Wasito dan Poewadarminto, 1980 : 87). Wahab, dkk 
(1986:341) memberikan pengertian metode inquiry adalah suatu cara belajar untuk mencari dan menemukan sesuatu secara kritis, analisis, logis dan sistematis dengan menggunakan langkahlangkah tertentu dlam mencapai kesimpulan yang meyakinkan berdasarkan data dan fakta interprestasi yang dapat diuji. Yusuf dan anwar (1995:82) mendefinisikan metode inquiry adalah suatu metode pengajaran dengan cara guru menyuguhkan peristiwa kepada murid yang menimbulkan teka-teki dan memotivasikan murid untuk mencari pemecahan masalah.

Metode inquiry memberi kessempatan kepada murid untuk aktif dan belajar mencari dan menemukan sendiri, guru tidak menyajikan bahan pelajaran dalam bentuk vinal, tetapi memberi peluang kepada murid untuk mengembangkan potensi intelektualnya melalui suatu kegiatan yang mereka susun sendiri untuk menyelesaikan masalah yang sengaja yang dihadapi kepada murid.

Untuk mengenal bentuk inquiry dengan baik maka perlu mengetahui ciri-ciri dasar metode inquiry sebagai berikut : (1) Merupakan metode mengajar dengan pendekatan sistematis dalam mencapai tujuan pengajaran yang telah direncanakan. Tujuan yang hendaknya dicapai mungkin merupakan tujuan jangka panjang maupun jangka pendek. (2) Cenderung melibatkan siswa sebanyak mungkin rasa ingin tahu dan rangsangan keterlibatan aktif dalam belajar, sehingga sifat pasif dapat dihindari, inquiry menghendaki keterlibatan murid secara konsisten. (3) Inquiry menghendaki pikran utama tungkat tinggi, esensi dari inquiry adalah suatu keterlibatan yang direncanakanbagi siswa dalam berpikir (wahab, dkk, $1986: 342$ ).

Dalam proses belajar mengajar yang menggunakan metode inquiry siswa dapat memetik berbagai manfaat diantaranya adalah : (1) Meningkatkn potensi intelektual dalam dirinya. (2) Dapat mencapai nilai intrinksik dari pengajaran. Hal ini terjadi karena dalam inquiry tekanan belajar beralih dari penilaian secara ekstrinsik ke instrinsik. (3) Bertambahnya kemampuan memahami hakekat heuristic dari kegiatan inqury. Kemampuan itu merupakan alat yang efektif yang dapat digunakan dalam mengahadapi berbagai keadaan. (4) Dengan dikuasai metode inquiry siswa memiliki alat bantu dalam mengingat sesuatu. Dengan alat bantu siswa dapat mengorganisasikan bahan-bhan sedemikian rupa sehingga mudah diingat dan ditemukan kembali bila mana diperlikan dan tidak hanya menjadi barang simpanan (wahab, dkk, 1986:344). Seorang guru yang menggunakan metode inquiry secara dalam proses belajar mengajar, diharapkan guru memiliki pemahaman dan keterampilan sebagai berikut : (1) Memahami dan menghargai berbagai cara belajar yang digunakan siswanya. (2) Menguasai langkah-langkah kegiatan inquiry dan dapat menjelaskan kegiatan siswa berikut penjelasan jenis keterampilan yang diperlukan setiap langkah tersebut. (3) Kemampuan mengolah dan mengajukan pertanyaan untuk mengungkapkan berbagai cara kemapuan berpikir murid. (4) kemahiran dan mencari, merumuskan dan menjelaskan permasalahan untuk dijadikan bahan inquiry. (4) Kemampuan dalam mencari dan menyediakan bahan instruksional yang akan diperlukan dalam inquiry. (5) Kemampuan membina dan mendorong gairah untuk mengetahui sesuatu (pada siswanya) serta kemampuan berpikir sendiri (siswanya). (6) Membantu murid dalam mencari dan menilai data serta sumber data ( Wahab, dkk, $1986: 345$ )

Dalam system belajar mengajar guru menyajikan bahan pelajaran tidak dalam bentuk yang final, tetapi anak didik dberi peluang untuk mencari dan menemukan sendiri dengan menggunakan teknik pendekatan pemecahan masalah.

Secara garis besar prosedurnya adalah : (1) Simulation, guru mulai bertanya dengan mengajukan persoalan atau menyuruh anak didik membaca atau mendengarkan uraian yang memuat permasalahan. (2) Problem statement, anak didik diberi kesempatan mengidentifikasikan berbgai permasalahan, sebagian besar memilihnya dipandang paling menarik dan fleksibel untuk dipecahkan. Permaslahan yang dipilih itu selanjutnya dirumuskan dalam bentuk pertanyaan atau pertanyaan (statement) sebagai jawaban sementara atas pertanyaan yang diajukan. (3) Data collection, untuk menjawab pertanyaan itu membuktikan benar tidaknya, anak didik diberi kesemptan untuk mengumpulkan (collection) berbagai informasi yang relevan, membaca literatur, mengamati obyek, wawancara dengan nara sumber, melakukan uji coba sendiri.

\section{METODE PENELITIAN}

Lokasi pelaksanaan pembelajaran adalah di Sekolah SDN 4 Kalimas Kecamatan Teluk Batang Kabupaten Kayong Utara. Waktu pelaksanaan penelitian Bulan Agustus sampai November 2018. Mata pelajaran yang akan dilaksanakan perbaikan adalah Ilmu pengetahuan Alam (IPA) / Sains. Kelas yang akan dilakukan perbaikan pembelajaran adalah kelas V Semester I. Siswa berjumlah 20 orang, 10 laki-laki dan 10 permpuan.. 
Siswa masih sering rebut didalam kelas.Dengan memperhatikan identifikasi masalah dan rumusan masalah, maka penulis akan melaksanakan perbaikan pembelajaran. Rencana perbaikan pembelajaran ini akan dilaksanakan dlam mencari jalan keluar atau solusi serta mengatasi masalahmasalah dalam pembelajaran IPA di kelas V. Rencana perbaikan pembelajaran ini dilaksanakan 2 kali tatap muka setiap mata pelajaran setelah diketahui data awal hasil observasi.

Pelaksanaan Siklus I melputi : Materi pembelajaran adalah cirri-ciri dan Waktu pelaksanaan adalah Kamis, 15 Oktober 2018. Metode pembelajaran yang digunakan adalah informasi dan tugas.

Pelaksanaan Siklus II meliputi : Materi pembelajaran adalah cirri-ciri dan kebutuhan Mahluk Hidup. Waktu pelaksanaan adalah Senin, 26 November 2018. Metode pembelajaran yang digunakan adalah informasi, Tanya jawab, dan tugas.

Pelaksanaan Siklus III melimputi : Materi pembelajaran adalah cirri-ciri dan kebutuhan Mahluk Hidup. Waktu pelaksanaan adalah Kamis, 16 November 2018. Metode pembelajaran yang digunakan adalah metode inquiry.

Data yang penulis dapatkan adalah dengan menggunakan / melaksanakan observasi dan tes. Dari masing - masing siklus penilai telah mengadakan perbaikan. Siklus II merupakan refleksi dari siklus I. Sedangkan Siklus III merupakan refleksi dari siklus II.

\section{HASIL DAN PEMBAHASAN PENELITIAN Hasil Penelitian Per Siklus}

Dari temuan yang diperoleh penulis dan berdasarkan diskusi dengan teman sejawat serta supervisor, bahwa selama pembelajaran perbaikan dilaksanakan yaitu tiga siklus baik siklus I, II, dan III terdapat kemajuan yang berarti.

Pada Siklus I dilaksanakan pencapaianharapan berdasarkan prosentase yang ada sebagai titik awal untuk mengetahui ada atau tidaknya kemajuan perhatian siswa terhadap mata pelajaran IPA dengan penerapan metode Inquiry.

Pada siklus ke II boleh dikatakan bahwa proses perbaikan pembelajaran berhasil dengan baik. Hal ini disebabkan pada waktu proses perbaikan pembelajaran guru memberikan penerapan metode Inquiry dalam pembelajaran sehingga perhatian dan minat belajar siswa mulai nampak antusias dan bergairah. Boleh jadi materi yang diberikan juga menarik siswa sehingga siswa mudah menerima materi.

Pada siklus yang ke III untuk mata pelajaran IPA penulis membandingkan perolehan pada siklus I dan II apakah penerapan metode inquiry dapat meningkatkan perhatian minat siswa dalam belajar. Dengan melihat prosentase keberhasilan siswa dari nilai formatif ternyata terdapat kemajuan yang cukup baik dari hasil perbaikan pembelajaran dapat dicapai sesuai harapan dan tujuan. Meskipun dari ketiga siklus tidak satupun mencapai $100 \%$ keberhasilan. Hal ini penulis sadari dalam satu kelas intelegensi siswa tidak sama dan pasti ada yang intelegensinya rendah. Di samping itu bahwa dalam proses belajar mengajar banyak hal yang mempengaruhi hasil belajar siswa.

Tabel 1. Data Sebelum Diberikan Perhatian Dengan Menggunakan Metode Inquiry Dalam Pembelajaran.

\begin{tabular}{cccl}
\hline No & Criteria & Mata pelajaran IPA & \multicolumn{1}{c}{ Keterangan } \\
\hline 1 & Rendah & $45 \%$ & Soal tes formatif \\
\hline 2 & Sedang & $35 \%$ & 5 butir soal \\
\hline 3 & Tinggi & $20 \%$ & \\
\hline
\end{tabular}

Sumber : Data Test siswa Pra Siklus tanggal 29 September 2018.

\footnotetext{
Sedangkan setelah diberikan perhatian dengan metode inquiry oleh guru dalam

pembelajaran perbaikan siklus pertama maupun kedua diperoleh hasil sebagai berikut:
} 
Tabel 2. Data Sesudah Diberikan Perhatian Dengan Menggunakan Metode Inquiry Dalam Pembelajaran.

\begin{tabular}{cccc}
\hline No & Criteria & Mata pelajaran IPA & Keterangan \\
\hline 1 & Rendah & $20 \%$ & Soal tes formatif \\
\hline 2 & Sedang & $35 \%$ & 5 butir soal \\
\hline 3 & Tinggi & $45 \%$ & \\
\hline
\end{tabular}

Sumber : Data perolehan siswa siklus III tanggal 16 November 2018

\section{Pembahasan dari setiap siklus Siklus 1}

Pelaksanaan : siklus I terdiri dari 2 kali pertemuan atau peneliatian tiap peertemuan 2 jam pelajaran 2 x 35 menit. Kegiatan pembelajaran I atau tindakan I diawali dengan penjelasan proses pembelajaran dengan metode inquiry. Aturan ketika menjaring pendapat dan pelaporannya dan mengingatkan murid untuk memanfaatkan waktu sebaik-baiknya. Dengan metode ceramah dan tanya jawab guru menjelaskan pelajaran sambil merangsang (menstimulir) siswa untuk berfikir aktif dengan pendekatan pemecahan masalah tentang topik - topik yang akan dibagikan pada masing-masing kelompok dan mendorong murid untuk membuat interprestasi, penjelasan dan menyusun pendapat atau hipotesis sederhana pada jam kedua dari pertemuan I tersebut, murid berdiskusi dari pada masing - masing kelompok untuk menyaring pendapat dan melaporkan pada diskusi kelas.

Aktivitas belajar siswa dari hasil tes terulis diperoleh gambaran bahwa peningkatan aktivitas murid, dari sebelum siklus I dan sesudah siklus I masih kurang, pada buti-butir criteria yang diamati khususnya perhatian siswa masih sangat kurang.

Tabel 3. Daftar Hasil Siklus I

\begin{tabular}{llccc}
\hline No & \multicolumn{1}{c}{ Kriteria Yang Diamati } & $\begin{array}{c}\text { Jumlah } \\
\text { Siswa }\end{array}$ & Prosentase & $\begin{array}{c}\text { Dari Jumlah } \\
\text { Siswa }\end{array}$ \\
\hline 1 & Murid yang memiliki buku pelajaran & 15 & $75 \%$ & 20 \\
\hline 2 & Murid yang menyimak pelajaran & 12 & $60 \%$ & 20 \\
\hline 3 & Murid yang memperhatikan & 10 & $50 \%$ & 20 \\
\hline 4 & Murid yang merasa senang & 10 & $50 \%$ & 20 \\
\hline 5 & Murid yang mencatat pelajaran guru & 11 & $55 \%$ & 20 \\
\hline & Rata - rata & 12 & $58 \%$ & 20 \\
\hline
\end{tabular}

Sumber : Pengamatan Supervisor Pra Siklus tanggal 29 September 2018

Tabel 4. Daftar Hasil Sesudah Siklus I

\begin{tabular}{clccc}
\hline No & Kriteria Yang Diamati & $\begin{array}{c}\text { Jumlah } \\
\text { Siswa }\end{array}$ & Prosentase & $\begin{array}{c}\text { Dari Jumlah } \\
\text { Siswa }\end{array}$ \\
\hline 1 & Murid yang memiliki buku pelajaran & 15 & $75 \%$ & 20 \\
\hline 2 & Murid yang menyimak pelajaran & 16 & $80 \%$ & 20 \\
\hline 3 & Murid yang memperhatikan & 14 & $60 \%$ & 20 \\
\hline 4 & Murid yang merasa senang & 14 & $60 \%$ & 20 \\
\hline 5 & Murid yang mencatat pelajaran guru & 18 & $90 \%$ & 20 \\
\hline & Rata - rata & 15 & $75 \%$ & 20 \\
\hline
\end{tabular}

Sumber: Pengamatan Supervisor Siklus I tanggal 15 Oktober 2018

Hasil belajar siswa : Hasil belajar siswa sebelum siklus I jika dibandingkan dengan hasil belajar siswa setelah, siklus I terdapat peningkatan meskipun belum menunjukkan atau mencapai target minimal indikator keberhasilan. Hal tersebut dipengaruhi oleh kondisi fisik siswa karena cuaca / perubahan sistem belajar mengajar dari pasif ke aktif, perubahan pola berfikir dan faktor-faktor pada observasi di atas perbandingan tersebut lebih dijelaskan oleh tabel dibawah ini. 
Tabel 5. Rekapitulasi Prosentasi Hasil Belajar Siswa Sebelum Siklus.

\begin{tabular}{clccc}
\hline No & Kriteria Nilai & Rentang Nilai & $\begin{array}{c}\text { Jumlah } \\
\text { Nilai }\end{array}$ & Prosentase \\
\hline 1 & Sangat Baik & $80-100$ & 4 & $20 \%$ \\
\hline 2 & Baik & $60-79$ & 7 & $35 \%$ \\
\hline 3 & Kurang & $0-59$ & 9 & $45 \%$ \\
\hline & Jumlah & & 20 & 100 \\
\hline
\end{tabular}

Sumber : Data Test siswa Pra Siklus tanggal 29 September 2018

Tabel 6. Rekapitulasi Prosentasi Hasil Belajar Siswa Setelah Siklus.

\begin{tabular}{clccc}
\hline No & Kriteria Nilai & Rentang Nilai & $\begin{array}{c}\text { Jumlah } \\
\text { Nilai }\end{array}$ & Prosentase \\
\hline 1 & Sangat Baik & $80-100$ & 9 & $45 \%$ \\
\hline 2 & Baik & $60-79$ & 7 & $35 \%$ \\
\hline 3 & Kurang & $0-59$ & 4 & $20 \%$ \\
\hline & Jumlah & & 20 & 100 \\
\hline
\end{tabular}

Sumber : Data test siswa siklus III tanggal 16 November 2018

Dari tabel hasil pengamatan diperoleh ratarata kelas 15 siswa atau $75 \%$, sedangkan yang memperhatikan sebanyak 14 siswa atau $60 \%$.

Dari tabel belajar murid sebelum siklus I diperoleh rata-rata kelas 5 dengan kriteria nilai sebagai berikut : (1) Yang mendapatkan nilai tinggi sebanyak 4 siswa atau $20 \%$. (2) Yang mendapatkan nilai sedang sebanyak 7 siswa atau $35 \%$ (3) Yang mendapatkan nilai rendah sebanyak 9 siswa atau $45 \%$.

Dari tabel belajar murid setelah siklus I diperoleh rata-rata kelas 5.84 dengan kriteria nilai sebagai berikut : (1) Yang mendapatkan nilai tinggi sebanyak 9 siswa atau $45 \%$. (2) Yang mendapatkan nilai sedang sebanyak 7 siswa atau $35 \%$. (3) Yang mendapatkan nilai terendah sebanyak 4 siswa atau $20 \%$.

Setelah selesai siklus I ditemukan beberapa hambatan dan mendiskusikan langkah selanjutnya dengan supervisor. (1) Murid belum dapat memanfaatkan waktu secara efektif dan efisien pada waktu menjaring pendapat baik pada kelompok kecilnya maupun diskusi kelas. (2) Lalu lintas pembicaraan belum terkendali dengan baik dan catatan kelompok kecil dan diskusi kelas belum focus.

Perlu penjelasan singkat kembali tentang pelaksanaan metode inquiry dan teknis dalam berdiskusi dalam menjaring pendapat agar pada siklus II hambatan dapat dikurangi. Berdasarkan hasil pada siklus maka perlu dilanjutkan ketahap siklus I.

\section{Siklus II}

Pelaksanaan siklus II 2 x pertemuan $(2 \times 35$ menit) kegiatan pembelajaran pertemuan I menjelaskan materi dan proses pembelajaran sebagaimana siklus II, menjelang diskusi kelompok dan pelaporannya pada diskusi kelas guru memberi pengarahan. Atas hal-hal yang menghambat pada proses siklus I pertemuan kedua dilaksanakan membahas diskusi kelas dibimbing oleh guru. Pada akhir pertemuan diadakan tes esay tertulis soal.

Aktivitas belajar murid dari hasil observasi dari 2 kali penelitian menjelaskan bahwa aktivitas siswa meningkat sebaimana hasil pengamatan teman sejawat yang tercantum dalam tabel berikut:

Tabel 7. Daftar Hasil Observasi Siklus II

\begin{tabular}{clccc}
\hline No & \multicolumn{1}{c}{ Kriteria yang diamati } & $\begin{array}{c}\text { Jumlah } \\
\text { Siswa }\end{array}$ & Prosentase & $\begin{array}{c}\text { Dari Jumlah } \\
\text { Siswa }\end{array}$ \\
\hline 1 & Murid yang memiliki buku pelajaran & 15 & $75 \%$ & 20 \\
\hline 2 & Murid yang menyimak pelajaran & 16 & $80 \%$ & 20 \\
\hline 3 & Murid yang memperhatikan & 14 & $60 \%$ & 20 \\
\hline 4 & Murid yang merasa senang & 14 & $60 \%$ & 20 \\
\hline 5 & Murid yang mencatat pelajaran guru & 18 & $90 \%$ & 20 \\
\hline & Rata - rata & 15 & $75 \%$ & 20 \\
\hline
\end{tabular}




\section{Sumber : Pengamatan supervisor siklus II tanggal 26 Oktober 2018}

Hasil belajar siswa sebelum penelitian jika dibandingkan dengan hasil belajar murid pada siklus II terjadi peningkatan lebih dari pada siklus dan hambatan-hambatan yang muncul sudah berkurang, meskipun belum juga mencapai target minimal ketentuan belajar. Hal tersebut disebabkan karena sebagai siswa masih belum mampu aktif secara konstan atau masih terbiasa pasif. Peningkatn hasil belajar siswa dapat dilihat pada tabel dibawah ini.

Tabel 8. Daftar Prosentase Hasil Belajar Siswa Setelah Siklus II.

\begin{tabular}{clccc}
\hline No & Kriteria Nilai & Rentang Nilai & $\begin{array}{c}\text { Jumlah } \\
\text { Nilai }\end{array}$ & Prosentase \\
\hline 1 & Sangat Baik & $80-100$ & 12 & $60 \%$ \\
\hline 2 & Baik & $60-79$ & 4 & $20 \%$ \\
\hline 3 & Kurang & $0-59$ & 4 & $20 \%$ \\
\hline & Jumlah & & 20 & 100 \\
\hline
\end{tabular}

Sumber: Data test siswa siklus II tanggal 26 Oktober 2018

Pada tabel observasi diperoleh rata-rata kelas 16 siswa atau $80 \%$ murid yang memperhatikan sebanyak 16 atau $80 \%$. Dari hasil belajar siswa setelah siklus II diperoleh rata-rata 6,55 dengan kriteria nilai sebagai berikut : (1) Yang mendapatkan nilai tinggi sebanyak 12 siswa atau $60 \%$. (2) Yang mendapatkan nilai sedang sebanyak 4 siswa atau $20 \%$ (3) Yang mendapatkan nilai terendah sebanyak 4 siswa atau $20 \%$ (4) setelah selesai siklus II ditemukan beberapa hambatan dan mendiskusikan langkah selanjutnya, dengan teman sejawat . (5) Murid sudah dapat memanfatkan waktu secara efektif dan efisien pada waktu menjaring pendapat baik pada kelompok kecil maupun kelas. (6) Lalu lintas pembicaraan mulai tekendali namun masih ada yang mendominasi pembicaraan dan sebagian kurang aktif dan catatan kelompok kecil sudah lebih focus dari sebelumnya. (7) Kepada murid perlu diberikan stimulasi dan motivasi agar semuanya terbiasa dan bisa aktif. (8) Berdasarkan siklus II murid diadakan penelitian lebih lanjut ketahap berikutnya.
Siklus III.

Pelaksanaan : Siklus III terdiri dari $2 \mathrm{x}$ pertemuan ( $2 \times 35$ menit) kegiatan pembelajaran pertemuan I menjelaskan materi di atas untuk mempertahankan aktifitas dan perhatian siswa. Guru masih perlu menstimulasi dan motivasi murid, kemudian murid mendiskusikan dalam kelompoknya dengan topic yang sudah ditemukan bagi masing-masing kelompok. Setelah itu masingmasing kelompok melaporkan rangkuman pendapatnya pada diskusi kelas pertemuan II dilaksanakan untuk mempertajam dan rangkumannya. Di akhir pertemuan diadakan tes essay tertulis sebanyak 5 soal.

Aktivitas belajar siswa, siklus III proses belajar mengajar mengalami perbaikan dan peningkatan baik aktivitas murid maupun prestasi hasil belajarnya bagaimana hasil pengamatan supervisor dan lembar obsevasi dalam tabel berikut

Tabel 9. Daftar Hasil Siklus III

\section{No \\ Kriteria yang diamati \\ Jumlah siswa Prosentase}

\begin{tabular}{clcc}
\hline 1 & Murid yang memiliki buku pelajaran & 19 & $95 \%$ \\
\hline 2 & Murid yang menyimak pelajaran & 16 & $80 \%$ \\
\hline 3 & Murid yang memperhatikan & 17 & $85 \%$ \\
\hline 4 & Murid yang merasa senang atas penjelasan guru & 16 & $80 \%$ \\
\hline 5 & Murid yang mencatat pelajaran guru & 18 & $90 \%$ \\
\hline & Rata - rata & 17 & $85 \%$ \\
\hline
\end{tabular}

Sumber : Pengamatan Supervisor siklus III tanggal 16 November 2018

Hasil belajar siswa : peningkatan hasil siklus III ternyata mengalami peningkatan yang besar sehingga melampaui target minimal ketuntasan belajar. Hal tersebut setelah diadakan perbaikan dan pengawasan guru secara intensif peningkatan tersebut dapat dilihat pada tabel . 
Tabel 10. Rekapitulasi Prosentase Hasil Belajar Siswa Setelah Siklus III

\begin{tabular}{|c|c|c|c|c|}
\hline No & Kriteria Nilai & Rentang Nilai & $\begin{array}{l}\text { Jumlah } \\
\text { Nilai }\end{array}$ & prosentase \\
\hline 1 & Tinggi & $6,5-10$ & 19 & $95 \%$ \\
\hline 2 & Sedang & $5,5-6,4$ & 1 & $5 \%$ \\
\hline 3 & Rendah & $0-5,4$ & 0 & $0 \%$ \\
\hline & Jumlah & & 20 & 100 \\
\hline
\end{tabular}

Sumber : Data test siswa siklus III tanggal 16 November 2018

Dari tabel pengamatan pada siklus II diperoleh rata-rata 16 siswa(80\%) meningkat menjadi 17 siswa (85\%) pada siklus III. Sedangkan siswa yang memperhatikan pada siklus II sebanyak 16 siswa $(80 \%)$ meningkat menjadi 19 siswa $(90 \%)$ pada siklus III.

Dari hasil belajar siswa setelah siklus III diperoleh rata-rata 7,29 dengan kriteria nilai sebagai berikut : (1) Yang mendapatkan nilai tinggi sebanyak 19 siswa atau 95\%. (2) Yang mendapatkan nilai sedang sebanyak 1 siswa atau $5 \%$. (3) Yang mendapatkan nilai terendah sebanyak 0 siswa atau $0 \%$.

setelah siklus III dari hasil pengamatan dan hasil observasi dan hasil belajar tidak perlu lagi diadakan penelitian karena telah mencapai target indikator untuk lebih jelasnya dapat dilahat dari tabel perbandingan observasi dan hasil belajar.

Tabel 11. Hasil Pada Siklus I, II, dan III

\begin{tabular}{|c|c|c|c|c|c|c|c|}
\hline \multirow[b]{2}{*}{ No } & \multirow{2}{*}{ Kiriteria Yang Dinilai } & \multicolumn{3}{|c|}{ Siklus } & \multicolumn{3}{|c|}{ Kategori } \\
\hline & & awal & $\mathbf{I}$ & II & II & $\mathbf{N}$ & $\mathbf{T}$ \\
\hline 1 & $\begin{array}{l}\text { Murid yang memiliki buku } \\
\text { pelajaran }\end{array}$ & $\begin{array}{c}15 \\
75 \%\end{array}$ & $\begin{array}{c}15 \\
75 \%\end{array}$ & $\begin{array}{c}17 \\
85 \%\end{array}$ & $\begin{array}{c}19 \\
95 \%\end{array}$ & $\mathrm{~N}$ & - \\
\hline 2 & $\begin{array}{l}\text { Murid yang menyimak saat guru } \\
\text { menerangkan }\end{array}$ & $\begin{array}{c}12 \\
60 \%\end{array}$ & $\begin{array}{c}16 \\
80 \%\end{array}$ & $\begin{array}{c}17 \\
85 \%\end{array}$ & $\begin{array}{c}16 \\
80 \%\end{array}$ & $\mathrm{~N}$ & - \\
\hline 3 & Murid yang memperhatikan & $\begin{array}{c}10 \\
50 \%\end{array}$ & $\begin{array}{c}14 \\
16 \%\end{array}$ & $\begin{array}{c}16 \\
80 \%\end{array}$ & $\begin{array}{c}17 \\
85 \%\end{array}$ & $\mathrm{~N}$ & - \\
\hline 4 & $\begin{array}{l}\text { Murid yang senang dengan } \\
\text { pelajaran guru }\end{array}$ & $\begin{array}{c}10 \\
50 \%\end{array}$ & $\begin{array}{c}14 \\
60 \%\end{array}$ & $\begin{array}{c}15 \\
75 \%\end{array}$ & $\begin{array}{c}16 \\
80 \%\end{array}$ & $\mathrm{~N}$ & - \\
\hline 5 & $\begin{array}{l}\text { Murid yang mencatat penjelasan } \\
\text { guru }\end{array}$ & $\begin{array}{c}11 \\
55 \%\end{array}$ & $\begin{array}{c}18 \\
90 \%\end{array}$ & $\begin{array}{c}16 \\
80 \%\end{array}$ & $\begin{array}{c}18 \\
90 \%\end{array}$ & $\mathrm{~N}$ & - \\
\hline
\end{tabular}

Sumber: Data test siswa siklus I s.d III

Keterangan : $\mathrm{N}=$ Naik $\mathrm{T}=$ Turun

Dari data diatas menunjukkan bahwa hasil pengamatan terhadap murid setiap kali penelitian : (1) Sebelum penelitian siswa yang memperhatikan 10 atau 50\% dari jumlah sisiwa. (2) Siklus I siswa yang memperhatikan 14 atau $90 \%$ dari jumlah siswa 20 terjadi peningkatan. (3) Siklus II siswa yang memperhatikan sebanyak 16 atau $80 \%$ dari jumlah siswa 20 terjadi peningkatan. (4) Siklus III siswa yang memperhatikan sebanyak 17 atau $85 \%$ dari 20 siswaterjadi peningkatan.
Prosantasi peningkatan perhatian siswa dari sebelum siklus sebanyak 20 siswa 50\%. Meningkat menjadi 17 atau $85 \%$. Setelah siklus III maka devisi peningkatan sebesar $85 \%$ dikurangi $50 \%$ sam dengan $35 \%$.

Dengan demikian data di atas menjelaskan bahwa dengan metode inquiry secara berangsur mampu meningkatkan pendidikan perhatian belajar siswa terhadap mata pelajaran IPA sebesar $35 \%$.

Tabel 12. Hasil Belajar Siswa Kelas V SDN 4 Kalimas Sebelum dan Sesudah Siklus I, II, dan III.

\begin{tabular}{cccccc}
\hline No & Nama Siswa & Awal & Siklus I & $\begin{array}{c}\text { Siklus } \\
\text { II }\end{array}$ & Siklus III \\
\hline 1 & NH & 40 & 50 & 65 & 70 \\
\hline 2 & SY & 55 & 60 & 70 & 75 \\
\hline
\end{tabular}




\begin{tabular}{cccccc}
\hline 3 & AA & 50 & 55 & 65 & 75 \\
\hline 4 & EI & 60 & 70 & 80 & 85 \\
\hline 5 & N & 70 & 75 & 80 & 85 \\
\hline 6 & RA & 60 & 65 & 70 & 75 \\
\hline 7 & TDA & 60 & 65 & 70 & 75 \\
\hline 8 & DS & 70 & 75 & 80 & 90 \\
\hline 9 & I & 55 & 65 & 75 & 80 \\
\hline 10 & RZK & 45 & 50 & 65 & 70 \\
\hline 11 & APY & 50 & 60 & 65 & 70 \\
\hline 12 & AI & 4.0 & 55 & 65 & 70 \\
\hline 13 & DS & 4.0 & 55 & 60 & 65 \\
\hline 14 & EA & 60 & 65 & 70 & 75 \\
\hline 15 & ETA & 70 & 75 & 80 & 90 \\
\hline 16 & FM & 60 & 65 & 70 & 75 \\
\hline 17 & PA & 60 & 65 & 70 & 75 \\
\hline 18 & RW & 45 & 55 & 65 & 70 \\
\hline 19 & RS & 55 & 65 & 70 & 75 \\
\hline 20 & SAK & 60 & 65 & 70 & 75 \\
\hline & Jumlah & 1025 & 1255 & 1405 & 1520 \\
\hline
\end{tabular}

Tabel diatas menunjukkan peningkatan hasil belajar dari sebelum dan diterapkannya penelitian dibandingkan dengan setelah penelitian pada siklus I, II, dan III. Peringkatan prestasi siswa sebelum diterapkan penelitian dan setelah diterapkan penelitian dengan menggunakan metode inquiry pada Kelas V SDN 4 Kalimas Kecamatan Teluk Batang Kabupaten Kayong Utara mengalami peningkatan seperti tertera pada tabel berikut :

Tabel 13. Rekapitulasi Prostase Peningkatan Hasil Belajar Sebelum Penelitian dan Sesudah Pelaksanaan Siklus I, II, III dari 20 Siswa.

\begin{tabular}{llllll}
\hline No & Rentang Nilai & Sebelum & \multicolumn{3}{c}{ Sesudah } \\
\cline { 4 - 6 } & & & \multicolumn{1}{c}{ Siklus I } & Siklus II & \multicolumn{1}{c}{ Siklus III } \\
\hline 1 & Tinggi & 4 siswa & $9 \%$ & 12 siswa & 19 siswa \\
& $65-10$ & $20 \%$ & $45 \%$ & $60 \%$ & $95 \%$ \\
\hline 2 & Sedang & 7 siswa & 7 siswa & 4 siswa & 1 siswa \\
& $55-64$ & $25 \%$ & $35 \%$ & $20 \%$ & $5 \%$ \\
\hline 3 & Rendah & 9 Siswa & 4 Siswa & 4 Siswa & - \\
& $0-54$ & $45 \%$ & $20 \%$ & $20 \%$ & \\
\hline
\end{tabular}

Sumber : Data hasil belajar siswa dari pra siklus - siklus III

Memperhatikan tabel di atas, membuktikan bahwa penerapan metode inquiry pada pelajaran IPA di Kelas V SDN 4 Kalimas Kecamatan Teluk Batang Kabupaten Kayong Utara Tahun Pelajaran 2018/2019 dapat meningkatkan prestasi, kreatifitas, perhatian dan hasil yang cukup baik untuk mengerti dan memahami pelajaran IPA sehingga metode ini cukup baik, jika digunakan untuk meningkatkan prestasi belajar anak didik.

\section{SIMPULAN DAN SARAN Simpulan}

Dari hasil penelitian tindakan kelas Siklus I, II, III yang diterapkan di Kelas V SDN 4 Kalimas
Kecamatan Teluk Batang Kabupaten Kayong Utara Tahun Pelajaran 2018/2019 dapat ditarik kesimpulan bahwa : (1) Terjadi peningkatan perhatian belajar mengikuti penelitian tindakan kelas Mata Pelajaran IPA sebesar $42.5 \%$ yaitu sebelum penelitian sebanyak $50 \%$ dan sesudah siklus II dan III sebesar 19 siswa (95\%). (2) Terjadi penelitian prestasi belajar setelah mengikuti penelitian tindakan kelas. Mata Pelajaran IPA sebesar $67 \%$. Sebelum penelitian sebanak 4 siswa (20\% yang memperoleh nilai 6,5 dan setelah penelitian meningkatkan menjadi 19 siswa 95\%). (3) Peningkatan perhatian dan prestasi belajar 
murid tersebut karena dipengaruhi penerapan metode inquiry pada pembelajaran IPA.

\section{Saran}

Selama penelitian siklus I, II, dan III ditemukan dan kekurangan dari metode inquiry, baik itu menyangkut guru, siswa maupun sekolah. Pada penulisan penelitian ini dan berdasarkan pengalaman tersebut penulis menggunakan saran, sebagai berikut : (1) Agar guru meningkatkan profesionalitas pembelajaran dengan melaksanakan penelitian tindakan kelas dan memvariasikan metode mengajarnya di antaranya dengan metode inquiry dengan pendekatan pemecahan masalah. (2) Sekolah hendaknya selalu berusaha meningkatkan layanan profesional pendidikannya dengan mendorong guru-guru untuk melakukan penelitian khususnya penelitian dalam bentuk penelitian tindakan kelas. (3) Setiap sekolah hendaknya menerapkan hasil-hasil penelitian pendidikan yang akan meningkatkan kinerja guru dan personil pendidikan lainya sehingga membantu mewujudkan misi dan visi sekolah.

\section{DAFTAR PUSTAKA}

A. Aziz Wahab, dkk, 1986 Materi Pokok Metodologi Pengajaran IPA, karunika Jakarta hal. $6-41$.

A. Suryadi. 1983, Membuat Siswa aktif Belajar, Bina Cipta Bandung. Hal. 105

IGK Wardani. 2002, Penelitian Tindakan Kelas, Jakarta, Pusat Unit Universitas Terbuka. Hal. $6-29$

Ngalim Purwanto. 1997, Psikologi Pendidikan Remaja, Karya CV, Bandung hal. 174

Saiful Bahri Djmarah Aswan Zain, 1996, Strategi Belajar Mengajar, Rineka Cipta Jakarta hal. 252

Slameto, Belajar dan Faktor-Faktor yang mempengaruhinya. Rineka Cipta Jakarta hal. 105

Sudirman dkk, 1986, Ilmu Pendidikan Remaja, Karya Jakarta hal. 285

Tim Pelatih Proyek OGSM, 1999, Penelitian Tindakan Kelas (Clas room Action Reserch) PGSM, Dirjen Dikti Depdikbud, Jakarta. Hal. 101 